\title{
Spirituality we do not have such a thing: patrimonialization processes as minefields
}

\begin{abstract}
Three vignettes are used as points of departure to identify the dynamics of the politics of recognition of indigenous patrimony, in terms of the languages of contention enabled to struggle for rights of the meta cultural disputes becoming apparent in and through that struggle and of the tensions resulting from the hegemonic attempt to equalize different economies of value and affection and regimes of historicity. Once the main paradoxes of patrimonialization processes are presented, their unintended consequences and perilous effects are analyzed in three steps. First, a critical reading of the contemporary governmentality is advanced as far as the definition of patrimony is concerned. Second, Mapuche participation in the commemoration of the fortieth anniversary of the last military coup in Bariloche is analyzed, as to identify predicaments resulting from the clash of patrimonializations that focus upon the same event, from perspectives that make different critical comments on history, the places of memory and the environment. Once the instabilities of meanings that the event made apparent are identified, alternatives are explored to walk through these "minefields", inherited from previous wars and current skirmishes.
\end{abstract}

Keywords: patrimonialization processes, intercultural arrangements, mapuche people, ethnographic museum, minefields
Volume 2 Issue 2 - 2017

\author{
Claudia Briones \\ Instituto de Investigaciones en Diversidad Cultural y Procesos \\ de Cambio, Argentina
}

Correspondence: Claudia Briones, Instituto de Investigaciones en Diversidad Cultural y Procesos de Cambio, Argentina, Tel 5492944429350,Email cbriones@conicet.gov.ar

Received: June 19,2017| Published: November 07, 2017

\section{Interesting paradoxical times}

As an anthropologist, different ethnographic situations are the matter that I find useful to identify the issues I want to think about. Three different ethnographic situations are useful to identify the main paradoxes that characterize the era we live in, as far as patrimonialization processes are concerned.

\section{About political languages}

Several years ago, a meeting was held in Buenos Aires, to discuss the legal frameworks that regulate the recognition of indigenous rights. Members of different native peoples had sent their representatives. State employees of the organism in charge of Argentina's indigenous policy and some anthropologists who use to collaborate with indigenous organizations and communities were part of the audience. In behalf of the Wichi people, two very young men presented the main concerns of their elders. Even if their Spanish was limited, they could at least communicate with us while their elders could have not expressed themselves in the state language. Hence both youngsters faced a difficult task. Visiting the capital city for the first time, a quite distressing experience in itself, they had to remain faithful to what they had been sent to transmit in front of very passionate addressees.

When they finished their presentation, a Mapuche participant asked them "But, brothers what about Wichi spirituality?" The two youngsters looked at each other in shock and after a tense silence, one of them replied: "Spirituality... we do not have such a thing". The awkwardness of the situation would have just become a funny anecdote, had it not been for the admonishment of the Mapuche activists, who censored the Wichis for neglecting the crucial importance that spirituality has for defining the identity and distinctiveness of indigenous peoples.

At that point, my discomfort turned into frustration. During the coffee break, I decided to put in plain words the paradoxical nature of the exchange to both my Wichi and Mapuche interlocutors. In spite of colonization, most Wichi children start school, speaking only Wichi. By contrast, most Mapuche children start school speaking only Spanish. Therefore the fluency in Spanish of different indigenous peoples in Argentina is very different, as much as the ways in which they fight for their rights. What I was trying to convey in the most respectful way I was capable of was that, while many Wichi practices attest for what it is defined as spirituality in political arenas and by some indigenous activists, labeling their practices as being spiritual makes no sense to them.

In any event, the issue at stake here not simply is the extent to which the language of indigenous rights conditions the ways in which demands can be advanced and defended, but mainly how becoming fluent in such a language might impact on how we think of our practices

\section{Culture and meta culture}

Many years ago too, some colleagues of the Ethnographic Museum of Buenos Aires invited experts in Patagonian Ethnology to discuss how to display Mapuche-Tewelche history and material culture. I can attest that my colleagues worked very hard and showed the most earnest disposition to come up with the most truthful exhibition of the pieces that the Museum possessed. They read a lot, shared doubts and accepted our many suggestions. During the opening, I asked a Mapuche youngster what he thought of the exhibition, assuming that the unique objects in display could have moved him. To my dismay, he replied: "I feel in rage. They are shamelessly showing what they have stolen from us. How can they have six rewes while we do not have any at home? Moreover, a rewe cannot be shown like that. Only the machi who owns it can raise it and take care of it."

Of course I knew that, as part of the shamanic realm, machis (healers) and rewes (the wooden set of steps they use to perform healing rituals) are very delicate things. Yet I also knew the aim of my 
colleagues. In Argentina, where it still is argued that only the "almost extinct" Tewelche people can be considered Argentine Indians, while the Mapuche people belong to Chile and thus have no indigenous rights whatsoever over argentine soil, my colleagues were trying to communicate the deepness and richness of the Mapuche roots east of the Andes--a perspective that my interlocutor also shares. However, very different ideas of what cultural heritage is--and of what we can do with it--were at play. For some, rewes represent the vividness of material culture. For others, rewes are not and cannot be treated as mere objects that anyone can see, possess or manipulate. Within intercultural contexts, the thingness of things is never an obvious matter.

As my initial surprise made me realize, this clash of readings and feelings shows that, even when we agree upon some political issues, we can do so abiding by different meta cultural standards of what culture is and thus of what can we do with it. Meta culture here refers to the fact that culture is, like language, both a means and an object of predication that, as Gregory Urban (2001) states, allows us to speak of culture in cultural terms. From my viewpoint, then, Meta culture refers to practices that produce their own regime of truth about what culture is and is not. ${ }^{1}$ Hence, Meta cultural standards at play should be a key aspect of any cultural analysis. And yet, the rage of the youngster also showed that the rewes that were displayed as material culture involve more than diverse meta cultural standards. They also point to ontological conflicts ${ }^{2}$ and thus they put forward disagreements of a different sort.

\section{Economies of value and affection}

I was also moved by an Arahuaco film which shows the day in which several mamos or spiritual leaders of the Sierra Nevada of Santa Marta went to the Colombian Museum of Gold to identify which Kogi and Arahuaco pieces had been stolen from their land. The Chair of the Museum was shocked indeed. Nervous as she was, she accepted to talk about the claim while the situation was being filmed. Meanwhile, some mamos wandered around the exhibition. One of them took a halt at a very small and broken piece, despite the many priceless, magnificent pieces that were on display. He admonished that that small piece should be taken back home. Asked about the other splendid pieces, the mamo replied: "I don't know about that, because I don't know to which earth breathing hole they belong to. I do know however the hole where this other piece should be taken back, to heal mother earth".

In any event, this scene points to the fact that, in addition to different metacultural standards, different economies of value and affection $^{3}$ as well as regimes of historicity ${ }^{4}$ are at play whenever disputes over cultural heritage take place.

\section{The contemporary governmentality about patrimony}

No doubt that UNESCO's conventions are an interesting hegemonic investment. Especially the 2003 convention's awareness and responsiveness to indigenous claims are very useful to back up unceasing demands of recognition and protection of their tangible and intangible heritage at the national, regional and international levels. In this regard, regulations of cultural heritage are part of a global politics of recognition that, in recent decades, has defined cultural diversity as an asset and not a burden, in other words, a politics attuned to a governmentality ${ }^{5}$ which has been extensively discussed as ethnogovernmentality, ecogovernmentality, neoliberal and multicultural governmentality and so forth. ${ }^{1}$ There is no doubt either that UNESCO's conventions are the result of a complex bid to create consensus among the contradictory interests of disparate actors. As a result, consensus not simply involves compromises, but mainly hegemonic closures in terms of meaning-making processes. Instead of analyzing the international regulations in themselves or the complex process of their negotiation, my interest rather lies on the identification of what I see as the key hegemonic closures that these regulations inscribe, as to be able to ponder later the room for maneuver that these closures leave open, for social praxis to vie for different claims. In fact, my true concern and experience lie on the likelihood of using such room for maneuver and on assessing the effects of different forms of doing so.

The reference to patrimonialization processes as minefields aims at acknowledging that hegemonic closures set the layout of a complex field of struggle, but also that they cannot establish predictable outcomes once and for all. As Stuart Hall ${ }^{6}$ would have probably said about heritage-making, social praxis does its own work, trying to walk safely through minefields, but always with no guarantees. Hence, the identification of the predicaments and effects of patrimonialization processes upon the grass-roots requires first mapping those minefields.

The first thing to acknowledge is that the very idea of cultural heritage frames intangible practices and their tangible outcomes into a semantic field which clearly belongs to a capitalist economy of value. Whether we choose to speak of cultural patrimony or property, of cultural resources or social capital, cultural diversity acquires the character of possessions, a sort of wealth that can be accumulated, that can be shared or rather be withdrawn from circulation, that can be culturally consumed in and through museums, festivals, tourism.

Even when we want to move away from this frame, we fall once and again in economic metaphors that condition our thinking and practice. For instance, UNESCO's page explaining "What is Intangible Cultural Heritage?" states that the cultural heritage "does not end at monuments and collections of objects. It also includes traditions or living expressions inherited from our ancestors and passed on to our descendants, such as oral traditions, performing arts, social practices, rituals, festive events, knowledge and practices concerning nature and the universe or the knowledge and skills to produce traditional crafts." Hence, not only the materiality of the material is at stake. However, UNESCO also clarifies that "the importance of intangible cultural heritage is not the cultural manifestation itself but rather the wealth of knowledge and skills that is transmitted through it from one generation to the next" wealth being here the key concept. ${ }^{2}$ Yet my concern does not simply go in the direction of the Comaroffs ${ }^{37}$ worries regarding ethnic heritage becoming an asset and thus ethnic groups becoming corporations because, where I live and work, such corporativization is a very unlikely prospect. I am rather mainly concerned with the possibility that policies of recognition become an iron cage that forces indigenous peoples to speak the language of cultural patrimony under conditions that, not being of their choosing, recreate their sub-alternity. Let's expand on this idea.

In their 2009 book, the Comaroffs ${ }^{7}$ are right in stressing that, in some contexts, culture becomes a commodity and that, as a result,

${ }^{1}$ See for instance Boccara 2007; Hale 2002, Ulloa 2004

${ }^{2}$ UNESCO's quotes in this paragraph are available at https://ich.unesco.org/ en/what-is-intangible-heritage-00003. Unless otherwise is stated, following UNESCO's quotes are available in the same page. 
any social identity which is transformed into the legal subject of intellectual property rights may be essentialized. As Slavov Žižek ${ }^{8}$ would say, once we capitulate to the idiom of intellectual property, capitalism taints everything, even non capitalist practices. But I see two even more dangerous displacements. I refer first to the commodity fetishism which is involved, by which social relationships among people end up being seen as relationships among things with intrinsic value. Second, I refer to the need of entitling owners, as if ownership were the only way of conceiving relations and practices.

In the first direction, common sense understandings tend to fetishize objects and practices by assigning them intrinsic value to perform several tasks. According to UNESCO, "cultural heritage is an important factor in maintaining cultural diversity in face of growing globalization" and thus a suitable investment that "helps with intercultural dialogue and encourages mutual respect for other ways of life". Somehow, the expectations involved in these transactions resonate with the optimistic language that promotes future markets. ${ }^{9}$

In the second direction, the identification of owners lumps together culture and identity again, two frames of social life that Anthropology has fight hard to de-couple. In this regard, defining ownership has, more often than not, an imploding capacity among those who are prompted to start thinking of themselves as inheritors. I witnessed many situations in which it was hard to define pros and cons of promoting the UNESCO's recognition of the gillatun, for instance the collective ritual of offering to express gratitude to spiritual beings, as cultural heritage of the Mapuche people. I will come back to this initiative later.

The second hegemonic closure that I see as very problematic derives precisely from the coupling of culture and identity, because it brings us back to what Susan Wright ${ }^{10}$ characterizes as the view of society as a mosaic of cultures. This archipelago vision which is allpervading in the UNESCO's Report called Our Creative Diversity, ${ }^{11}$ sees the world as made up of 'peoples' each with a different 'culture' like a string of separate islands. It thus obscures the dimension of 'culture' and I quote Wright "as a process of contestation over the power to define organizing concepts - including the meaning of "culture' itself. ${ }^{10}$ " In other words, in its vision of a new ethical world order, UNESCO's discourse about cultural diversity and patrimony ends up mapping out a world made of 'cultures' as discrete entities, without engaging with the issue of contestation over the power to define them.

When cultural heritage is at stake, thinking of social complexity as a mosaic composed of more or less uniform pieces forces people to identify edges as the result of cultural differences between practices and not within a practice. Consequently, even if the Mapuche people have been speaking Spanish for centuries, they cannot think of it as their language, but always as the colonizer's language, a very alienating way of visualizing their everyday practice which, moreover, is always measured up against the fluency and communicative style of non indigenous people. ${ }^{1}$

I know that, when UNESCO's ${ }^{12}$ Convention defines intangible cultural heritage as "inclusive", it aims at avoiding the "question of whether or not certain practices are specific to a culture", in the persuasion that cultural heritage can "contribute to social cohesion, encouraging a sense of identity and responsibility which helps individuals to feel part of one or different communities and to feel part of society at large". Unfortunately, this is not the way in which people that think of them as having been expropriated of everything understand inclusiveness. Transforming "their" patrimony into everybody's wealth or into a "human treasure" can be seen as another act of spoliation that masks the many inequalities that still organize social life.

There also is a third hegemonic closure that the UNESCO's ${ }^{12}$ Convention makes explicit, when asserting that "consideration will be given solely to such intangible cultural heritage as is compatible with existing international human rights instruments, as well as with the requirements of mutual respect among communities, groups and individuals and of sustainable development." It is obvious that we need agreements and that coexistence should be negotiated. The issue here is who is invited to the negotiating table with real power to decide.

When judging the scope of the UNESCO Report Our Cultural Diversity, ${ }^{13}$ Susan Wright ${ }^{10}$ notes that "UNESCO's vision of a code of global ethics to order a plural world rests on a contradiction between respecting all cultural values and making value judgments about acceptable and unacceptable diversity".${ }^{10}$ In fact, an unidentified voice does the defining, while disclaiming its own power as common sense. In the same direction, the UNESCO's ${ }^{13}$ Convention on the Protection and Promotion of the Diversity of Cultural Expressions proclaims that "cultural diversity forms a common heritage of humanity" and must be protected, but only if "human rights and fundamental freedoms ... are guaranteed".

The point to be stressed is that the authority of UNESCO to create a global lingua franca for recognizing cultural heritage recreates unintendedly, perhaps--political arenas fraught with inherent tensions. These tensions determine in Raymond Williams ${ }^{14}$ terms, that is set initial conditionings under which social praxis can work. Hence, they intervene social praxis itself. Tensions and contradictions result not only from the fact that heteroglossic visions of what is at stake must comply with the universalizing language empowered to speak about them, but also from the fact that everything that peoples try to defend as their own tends to be transformed into widespread wealth, into human treasures and also from the fact that very new and alien devices are in order to objectify practices whose value depends on being inherited traditions.

Hence, the transformation of practices into "Cultural Heritage" or "Cultural Property" cannot be seen just as a controlled equivocation in Viveiros de Castro's ${ }^{15}$ sense. It must rather be taken as a domineering translation that uses one particular economy of value and affection, the capitalist economy of value and affection, as standard to normalize other regimes of value and affection. I thus prefer not to approach claims about cultural practices as "resources", but as indicators of the ways in which past and present asymmetries are contested. In other words, by pointing to the political dimensions of metacultural disputes about cultural patrimony, I move away from cultural practices as such, to analyze their becoming indexes of the politicization of intercultural arrangements.

No doubt, the Mapuche people have taken into account UNESCO's conventions to vie for the recognition of what they want to preserve or display as core to their belonging. For instance, the gillatun or gillipun has been put under discussion as icon of their intangible heritage and belonging. In formal terms, the gillatun meets the requirements of the ${ }^{12}$ Convention to be recognized as intangible heritage. ${ }^{16}$ Yet, debates were intense indeed within the "in" group. The private character of 
Mapuche ritual practices in particular has been the most controversial issue, since not everybody would agree on the publicization and politicization of Mapuche spirituality.

However, instead of focusing on this kind of straightforward patrimonializing process insofar as it demands the recognition of a practice that can only be under Mapuche control, like the gillatun I choose to explore Mapuche claims which, more often than not, are invisibilized or overtly questioned, because they cast doubt on hegemonic heritage making processes with which they are in conflict. To better understand the complexities of what is at stake, I focus on disagreements which involve the argentine society at large and thus frame heritage-making processes into much more volatile and uncomfortable horizons. By exploring unstable horizons from below, I do not want to blame good legal frames of bad results. I just want to look at more suppressed aspects of intercultural battles around heritages.

\section{Uncomfortable patrimonializations}

San Carlos de Bariloche is a small yet touristic city, located in one of the most beautiful spots of Norpatagonia. This "little town", as their neighbors call it, offers activities for both summer and winter holydays. Embedded in a National Park since the 1930s, when the National Park Nahuel Huapi was created, the city profile has been carefully shaped in terms of landscape, architecture and selfrepresentation as the argentine Switzerland. Declaring itself proud of being the result of the efforts of pioneers from central Europe, many of its indigenous inhabitants--who live in the poorest neighborhoods-still tend to avoid self-identifying themselves as Mapuche-Tewelche in public (Figure 1).

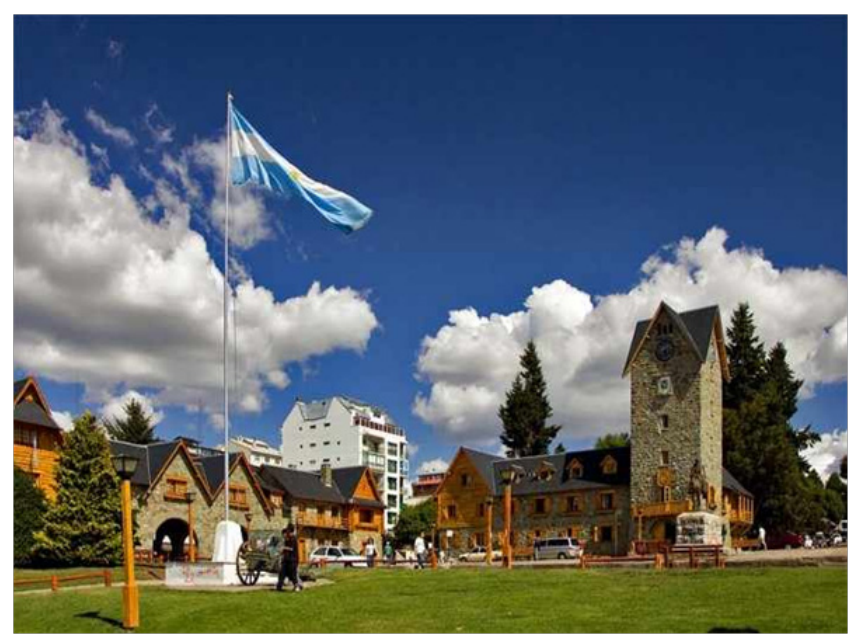

Figure I Centro Cívico of San Carlos de Bariloche, touristic image.

Yet, both Bariloche's public profile and the silence of part of its inhabitants conceal what Mapuche activism has been expressing loudly for decades now, that Bariloche is part of the Wall Mapu or Mapuche territory, home of the lafkenche of Pwel Mapu, or people from the lake, east of the Andes. In contrast, the main reference to Bariloche's history before the arrival of the European pioneers is at odds with such a claim.

In the middle of the Square called the Centro Cívico Civic Center, one of the most touristic images of the city the statue of General Julio Argentino Roca, the military commander of the so-called "Conquest of the Desert", is placed celebrating the state advance over Indian Territory in Patagonia during the last decades of the nineteenth century. Every now and then and despite its smallness, Bariloche becomes the scenario of vivid political debates that also impact in and through the national arena. The Centro Cívico becomes, like the Plaza de Mayo of Buenos Aires, the square in which conflicting political demonstrations take place.

As a result, every March 24th, the date when Argentina's last military coup started in 1976, white head kerchiefs are painted and repainted in the square floor, to commemorate not simply the coup, but mainly the rounds of the Mothers of Plaza the Mayo, the Human Rights movement who stood up against the military, demanding the appearance of their missing children. Thirty thousand of them are mothers and Grandmothers of Plaza de Mayo thus are the icons of three mottos that summarize the ways in which most Argentines try to deal with one of the most painful periods of our political history: "Alive they took them away from us. Alive, we want them back"; "Never Again" and "Memory, Truth and Justice" (Figure 2).

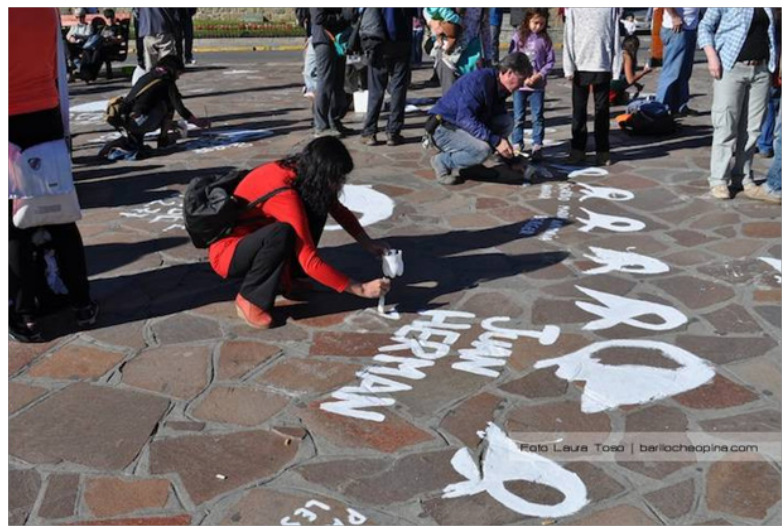

Figure 2 The painting of white headcherchiefs.

Mapuche individuals and organizations use to take part of these commemorations. They also have made different interventions against the Roca statue, questioning its being the symbol of Bariloche. The most famous or recalled one has been the kultrunazo, that is, the covering up of Roca statue in 2008 with a kulxun or ritual drum which is key part of the machi's activities and most Mapuche ceremonies. ${ }^{3}$ Some Human Rights organizations support Mapuche demonstrations, as much as Mapuche organizations attend theirs. However, despite this political convergence, the staging of Mapuche claims has always been "Mapuche stuff" and Human Rights' demands tend to remain quite mute about indigenous claims. But something changed in March 2016, when the fortieth anniversary of the coup was commemorated. On the one hand, labor unions, social organizations and political parties could not agree upon three main issues. Namely, how tough should be the criticisms against the new administration that started in December 2015, how explicit should be the support of the previous administration; and how to position themselves vis-a-vis the arrival of President Obama to Bariloche, precisely on March 24th. Therefore, two different commemorations started being organized. The agreement was that the supporters of the Kirchner couple that ruled the country for twelve years would paint the head kerchiefs the evening before and march to the Centro Cívico the following morning, while the Human Rights's organization HIJOS (children of the missing persons)

${ }^{3}$ Reference available at http://www1.rionegro.com.ar/diario/diario/2008/10/12/ imprimir.1223783303234.php 
and leftist parties would repaint the head kerchiefs on the morning of March the 24th and would march that same afternoon. Obviously, both parties would also make two different press releases.

On the other hand, a Mapuche political collective, the so-called Espacio de Articulación Mapuche y Construcción Politica, Space for Mapuche Articulation and Political Construction, not simply decided to take sides with Human Rights organizations because they had always marched with them. They mainly decided that, this time, they would demand for the introduction in the press release of a paragraph stating that state terrorism has not begun in the 1970 s, but a century before, when General Roca commanded the genocide against the Mapuche-Tewelche people in Patagonia. Indeed, some things had changed already. Almost a year ago, this organization proposed and achieved the passing of a decree by which Bariloche has recognized itself as an intercultural municipality. Therefore, from then on, the Mapuche organization assumed that every commemoration should display Bariloche's intercultural constitution. Hand in hand with the discursive coupling of both genocides as showing the violent bias of the Argentine state, both genocides should be explicit part of the artistic interventions to be done in the Centro Cívico.

Even among those that had decided to march together, the writeup of the press release took several meetings and harsh debates. The paragraph proposed by the Mapuche organization had been accepted but, two days before March 24th, it was clear that two different releases would be put forward by the circumstantial allies of this heterogeneous group. The Mapuche space decided that they would not sign any of the documents, because neither the behavior of each faction nor their debates represented the Mapuche interests and ways of doing politics. However, the Mapuche space would keep its word and would march with them, displaying images of their own casualties of war. Their supporters would also paint their own markers, to make visible the first génocide. Instead of painting a head kerchief, a kulxun would symbolize anonymous and well-known victims of the Conquest of the Desert (Figure 3).

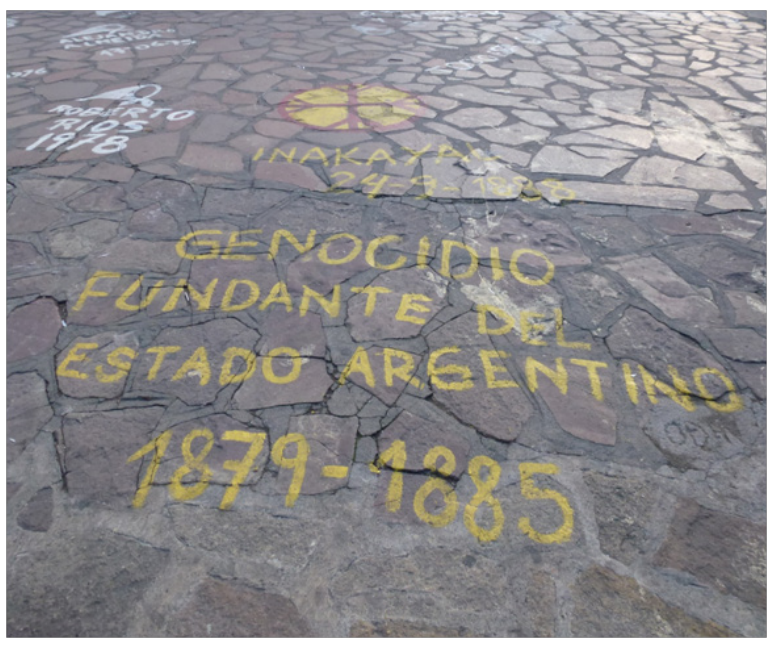

Figure 3 Kulxun side by side white headcherchiefs.

As a result of such a troubled context that split apart citizens who should remain united in the name of a common repudiation of state terrorism, as everybody expected, some Mapuche people marched with the unions in the morning, others marched in the afternoon and even others participated of both acts. The aftermath of the commemoration was not less controversial either. Few days after March the 24th a signature collection campaign started. In few days, more than five thousand signatories requested the Mayor and the City Council the cleaning of the paintings in the Centro Cívico, as to preserve and protect Bariloche's historical patrimony. Beyond the meaning of the white head kerchiefs, the document states, the mistreatment of a common heritage having historical and architectural value not only to the local community but also to the whole country was presented as an act of vandalism that conflicts with international, national and municipal regulations. The paintings not simply were depicted as an aesthetic problem that affects the touristic profile of the city, but mainly as an act promoting "social divisions, discomfort and anger, in a battered society". In the final analysis, the demand was presented as claiming for "respect for the history of the city, respect for those who choose us as a tourist destination and respect for all the signatories of the petition who are citizens like everybody else". While municipal employees received the order of cleaning Roca's statue, other opinions went public and added new dimensions to the debate about the signification of social memories, of historical monuments and of cultural heritage (Figure 4).

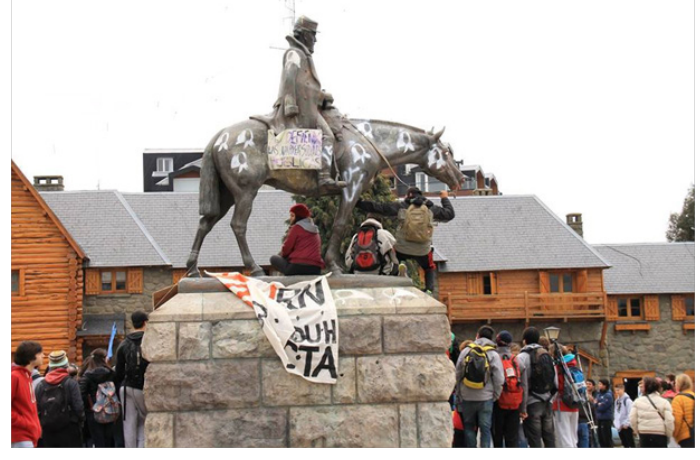

Figure 4 Roca's monument before being cleaned.

Unions and members of the two National Universities located in Bariloche positioned themselves against the ideological foundations of the individuals who demanded the cleaning of the head kerchiefs. The most radical proposals asked for the de-patrimonialization that is, the removal of Roca's statue, because it consecrates the first genocide. Defining the painting of head kerchiefs as a "popular expression that redefines the statue, adds socio-cultural value and strengthens the intent of the monument as a meeting place and expression of different sectors of society", members of the History Department of the National University of Comahue demanded that the painting of head kerchiefs be declared of cultural interest in the city. ${ }^{4}$ That is, head kerchiefs should be considered part of Argentina's intangible patrimony.

A war of patrimonies was clearly unleashed. If patrimonialization processes institute the exceptionality of particular "items" (objects, paintings, places, narratives and so forth) to express and represent metonymically values of a social whole or rather of a part of that whole, the conundrum that the head kerchiefs make visible relates less to identify appropriate items in themselves to embody universal or particular values of the citizenship, than to the very processes and mechanisms to define the values of whom deserve to be represented, ${ }^{17}$ as well as to if, where and how disputed values can share common public spaces.

${ }^{4}$ Declaration available at http://www.elcordillerano.com.ar/index.php/ actualidad/item/40046-piden-que-se-mantengan-los-panuelos-pintados-en-elcentro-civico 
In response, the City Council instructed the Commission for the Preservation of Historical, Urban and Architectural Heritage to define a management plan to regulate the use of the Civic Center from then on. The task that this Commission should face is not easy, for their members have to make and propose heritage choices that cannot please the three main positions under dispute. If one of them vies for a clean square that protects Roca's statue and Argentine Official History, the other expects that the statue be removed and only head kerchiefs remain, while some still imagine a square which makes room for the coexistence of conflicting memories and readings of Argentina's past, present and future.

Amidst such a backdrop, what does it mean to make room for a democratized heritage, socially created and locally anchored, which integrates alterity? How can the Commission identify a middle-ground which avoids the two possible extremes of omnipatrimonialization and de-patrimonialization that the Pater Mondi Consortium ${ }^{18}$ identifies as equally problematic? There is no doubt that the task that this Commission has been commanded to carry out will force its members to walk through minefields. How can this be done? If neither easy solutions nor neat responses can be advanced, at least some framing criteria can perform as closing remarks.

\section{Walking the minefields}

Tradition is never the result of a transparent meaning-making process. As Raymond Williams ${ }^{14}$ has stated, hegemonic traditions are always selective and tend to impose one particular vision on what is defined at the same time as residual or even archaic, or on what is rendered invisible as emergent. Cultural heritage works in the same direction, since what counts as patrimony is always built into the pursuit of cultural hegemony among and within social groups. If the pursuing of cultural hegemony or the very will of making hegemonic investments attempts to avoid leaving social coexistence to the operation of bare domination, the key point is how to promote the most thoughtful hegemonic investments.

It would be naive to expect that, through policies of heritage recognition, we could neutralize all social contradictions, inequalities and injustices. Yet we can and must democratize the processes of cultural heritization, as it is suggested by the Pater Mondi consortium, ${ }^{18}$ because cultural heritage is another field in which contradictions, inequalities and injustices express and recreates themselves. The discussion thus moves to the realm of what democratization means. Common-sense understandings use to relate democracy with the proactive production of consensus of the majority at least through institutional means. Against this idea, Roseberry ${ }^{19}$ points to hegemony as the agreement upon a common language of contention. According to Jacques Rancière ${ }^{20}$ however, disagreements that overflow standardized political languages become turning-points to move politics forward. From this perspective, the likelihood of democratizing the UNESCO's report ${ }^{11}$ would entail talking about Our Creative Disagreements instead of Our Creative Diversity.

Now then, if intercultural arrangements are the arena to make other commitments, as Arturo Escobar ${ }^{21}$ proposes, our chance of creatively navigating the seas of dissent depends of our acknowledging not simply conflicts, but the different kinds of conflict that disagreements make apparent. I refer to the recognition that, within intercultural arenas, social conflicts have distinctive dimensions, since divergences may be not only ideological, but also ontological and epistemological. In this regard, the Pater Mondi consortium is right when asserting that, rather than providing an a priori definition of heritage, emergent definitions of heritage by researchers, people on the ground, or other social actors should be taken into account. ${ }^{18}$ However processes of democratization within intercultural arenas entail not simply giving voice to different actors. It mainly depends on acknowledging that all the growing (social, political, economic) heterogeneities that processes of heritage-making presuppose relates not only to ideological, but also to ontological and epistemological disagreements that can express themselves in and through the same patrimonialized object.

The $p u$ kulxun painted along with the white head kerchiefs are a good example of what creative disagreements mean and how they can be read or made invisible. For some neighbors, the painting of pu kulxun expressed a Mapuche initiative that channeled Mapuche claims and perspectives with which those neighbors could agree or disagree upon. Beyond the circumstantial empathy or dissent with the pu kulxun's "conveyed message", all of these neighbors somehow assumed that $p u$ kulxun aimed at expressing particular values. However, as a means to create common awareness of intercultural arrangements, the initiative meant much more than that.

On the one hand, placing pu kulxun along with white head kerchiefs was less an act of disconnection, an act of staging a particular claim, than an act of showing a common repudiation of state terrorism and of claiming a common place in the right to disagree with the erasure of painful experiences. It also was an invitation to revisit the prevalent regime of historicity that confines Argentina's state terrorism to a very recent past and to some limited expression of political dissent. Placing pu kulxun along with white head kerchiefs showed fluency and agreement with the language of contention in use for four decades now to convey conviction about the strength of the "Never more" to state violence. In all these regards, pu kulxun performed a politicization of intercultural arrangements based upon demanding inclusion in common views about ideological conflicts.

Yet placing pu kulxun amidst white head kerchiefs in the four corners of the Centro Cívico also pointed to a different economy of value and affection. By signaling and protecting the four directions of the Wall Mapu, the pu kulxun presupposed and created the Centro Cívico as part of a broader view of the territory. By identifying each kulxun with well-known or anonymous casualties of state military state campaigns to Patagonia, the pu kulxun also enacted the constant, material presence and guidance of the kuifikeche or ancestors among the living. Like the ritual painting of the sacred horses during the gillipun, or the ritual painting of any kulxun, paintings enact a broad sense of more-than-human belonging, since they help to breach the gap and make communication possible across and among different beings and forms of existence.

Paradoxically, both the repudiation and the celebration of the Mapuche participation in this commemoration may end up reenacting annoying and recurrent invisibilizations. Whenever Mapuche participation in common spaces is celebrated or censored but merely judged as secondary or culturally idiosyncratic, neither the ways in which commonalities are being purported, nor the ontological and epistemological edges that are at the same time enacted are allowed to come into view. But more daringly, the painting of pu kulxun in the Centro Cívico questions the very idea of ownership that relates to common-sense understandings of patrimony. While common-sense understandings allow a certain patrimony to identify either the social whole or a distinctive part of it, the pu kulxun painted in the Centro Cívico on March 24th 2016 aimed at the same time at belonging to the 
whole and yet just to some part of the audience. In this regard, they point to a notion of intercultural arrangements that has not been fully understood yet.

Nowadays it could be easy to acknowledge that trying to define a common version of history from a single viewpoint will always be felt as oppressive or disrespectful by some. Still, it is less apparent that it will not do a better job the subscription to shallow multicultural notions and archipelago metaphors that make room for subalternized views as far as they remain subaltern or particular especially when these metaphors nurture a pasteurized, property-based notion of distinctive and clear-cut ethnic or national patrimonies. By contrast, richer and more sophisticated visions of intercultural coexistence can emerge when our disputes about heritage allow sustaining and exploring instead of neutralizing our cognitive, affective and moral disagreements, as well as our ontological, ideological and epistemological conflicts.

Rancière rightfully points out that the more difficult to read, to hear, to visualize and to understand social demands are, the more power they have to diagnose the flaws of ongoing coexistence arrangements. When expressed as demands of re-patrimonialization, objections to the choice of what items and how might re-present heritages simply point to perspectives that consider themselves invisible or excluded by the hegemonic ways of dealing with the identification of common as much as particular heritages, in material as much as historical, intellectual, affective or moral terms. Yet, these demands may not be pointing to neither plain incorporation nor plain differentiation, but to a much more complex way of depicting what intercultural coexistence entails. In this regard, as Rodney Harrison ${ }^{22}$ acknowledges, changing and disputed conceptions of heritage are thus positive in themselves, for they put forward different ontologies of assembling, valuing, caring for and making the future itself.

\section{Conclusion}

A different and more promising landscape for intercultural arrangements and thus democracy would emerge if, instead of being anxious and suspectful vis-a-vis conflicts and disagreements, we choose to think, with Tim Ingold, ${ }^{23}$ that we acquire knowledge through the process of travelling and of acknowledging similarities and differences with those whose journeys we share and whose paths we cross. If we choose to think, following Ingold, ${ }^{24}$ that the stories through which we represent the world trace paths that others can follow, there is no need to be fearful of walking the minefields, for such a perspective would transform those minefields into mesh works of paths having neither a point of origin nor any final destination and yet paths that would allow us to become alive in movement, as we go through them. Once the social is seen as a disputed, yet active and enduring, parliament of interwoven lines to dwell and travel as freely as possible, with no definite sense either of exclusive property or of forced belonging, the staging of disagreements will just be seen as a landscape of invigorated trails that will take us further. Then travelling across the meshwork of patrimonies would not be seen as a burden, but as a journey to bear with confidence and amazement. ${ }^{25-28}$

\section{Acknowledgements}

A preliminary version of this paper was presented at the Colloque FABRIQ’AM, “CULtURE : MODES D’emploI.

La patrimonialisation À L'épreuve des Amériques", held at París on June 2016. I am grateful to the organizers, Drs. Anath Vidal de Vidas and Valentina Vapnarski, as well as to the comments of the participants.

\section{Conflict of interest}

Author declares there is no conflict of interest.

\section{References}

1. Claudia B. Re-membering the Dis-membered: A drama about Mapuche and Anthropological Cultural Production in Three Scenes.4th ed. The Journal of Latin American and Caribbean Anthropology. 2003;8(3):31-58

2. Mario B. Ontological Conflicts and the Stories of Peoples In Spite of Europe: Towards a Conversation on Political Ontology. Current Anthropology. 2013;54(5):547-568.

3. Lawrence G. Popular Conservatism and Postmodern Culture. We Gotta get Out of This Place, Psychology Press, UK; 1992. p. 436.

4. François H. Regimes of Historicity: Presentism and Experiences of Time. European Perspectives: A Series in Social Thought and Cultural Criticism, Columbia University Press, USA; 2015. p. 262.

5. Michel F. The Foucault effect: studies in governmentality: with two lectures by and an interview with Michel Foucault. In: Burchell G, et al. editor. The University of Chicago Press, USA; 1991. p. 87-104.

6. Stuart H. The Problem of Ideology-Marxism without Guarantees. Journal of Communication Inquiry. 1986;10(2):28-44.

7. John C, Jean C. Ethnicity, Inc. The University of Chicago Press, USA; 2009.

8. Slavoj Z. Multiculturalism or the Cultural Logic of Multinational Capitalism. New Left Review. 1997;1(225):28-51.

9. Fernando C. Naturaleza del poscolonialismo: del eurocentrismo al globocentrismo. En La colonialidad del saber: eurocentrismo y ciencias sociales, Perspectivas latinoamericanas, Consejo Latinoamericano de Ciencias Sociales, USA; 2000. p. 53-67.

10. Susan W. The Politicization of 'Culture'. Anthropology Today. 1998;14(1):7-15.

11. UNESCO. Report of the World Commission on Culture and Diversity. Our Creative Diversity, UNESCO Publishing, France; 1996.

12. UNESCO. The Convention for the Safeguarding of the Intangible Cultural Heritage. 2003.

13. UNESCO. The Convention on the Protection and Promotion of the Diversity of Cultural Expressions. UNESCO Publishing, France; 2005.

14. Raymond W. Marxism and Literature. Oxford Universidad Press, USA; 1990.

15. Castro VD. Perspectival Anthropology and the Method of Controlled Equivocation. Tipit'1: Journal of the Society for the Anthropology of Lowland South America. 2004;2(1):3-22.

16. Guillaume B, Ayala P. La nacionalización del indígena en tiempos de multiculturalismo neoliberal. Forum for Inter-American Research. 2011;4(2):55-82.

17. Iñaki AU. Activaciones patrimoniales e iniciativas museísticas: ¿por quién? y ¿para qué? Servicio de Publicaciones, Spain; 2009. p. 427-429.

18. Maria GB. Foresight Workshop (FW). New Challenges for Cultural Heritage, Synthesis of the final report. Pantheon-Sorbonne University, France; 2014. p. 1-14. 
19. William R. Hegemony and the Language of Contention. In: Gilbert J, Nugent D, editors. Everyday Forms of State Formation: Revolution and the Negotiation of Rule in Modern Mexico. Duke University Press, USA 1994. p. 355-366.

20. Jacques R. El Desacuerdo. Política y Filosofía. Ediciones Nueva Visión. Argentina; 1996. p. 175.

21. Arturo E. Territories of Difference. Place, Movements, Life, Redes Duke University Press, USA; 2008. p. 456.

22. Rodney H. Heritage Critical Approaches. Routledge, USA; 2013. p. 272.

23. Tim I. When ANT meets SPIDER: Social theory for arthropods. In: Malafouris KL, editor. Material Agency Towards a non-Anthropocentric approach. Springer, 2008. p. 209-215.
24. Tim I. Lines. A brief history. Routledge, UK; 2007. p. 169.

25. Guillaume B. Etnogubernamentalidad. La formación del Campo de la Salud Intercultural en Chile. Revista de Antropología Chilena. 2007;39(2):185-207.

26. Charles H. Does Multiculturalism Menace? Governance, Cultural Rights and the Politics of Identity in Guatemala. Journal of Latin American Studies. 2002;34(3):485-524.

27. Ulloa Astrid. La construcción del nativo ecológico: complejidades, paradojas y dilemas de la relación entre los movimientos indígenas y el ambientalismo en Colombia, Instituto Colombiano de Antropología e Historia, Colombia; 2004. p. 364.

28. Gregory U. Metaculture: How Culture Moves through the World (Public Worlds). University of Minnesota Press, USA; 2001. 